\title{
Identifying program critical success factors in construction industry
}

\author{
Sarmad Kiani $^{\mathrm{a}^{*}}$, Vahidreza Yousefi ${ }^{\mathrm{a}}$, Siamak Haji Yakhchali ${ }^{\mathrm{b}}$ and Aghil Mellatdust ${ }^{\mathrm{c}}$
}

${ }^{a} \mathrm{PhD}$ candidate of Construction and Project Management, Faculty of Architecture, University Of Tehran, Tehran, Iran

${ }^{b}$ Assistant Professor, Faculty of Industrial Engineering, University of Tehran, Tehran, Iran

${ }^{c}$ MSc in Construction and Project Management, Faculty of Architecture, University of Tehran, Tehran, Iran

\section{H R O N I C L E \\ A B S T R A C T}

Article history:

Received December 28, 2013

Received in revised format April

152014

Accepted April 182014

Available online

April 182014

Keywords:

Construction industry

Program

Critical Success Factors

\begin{abstract}
In project management literature, the concept of program is a group of related projects managed in a coordinated way to obtain benefits not available from managing them individually. This paper attempts to identify program critical success factors focusing on Iran's construction industry so that the level of relative importance of various factors could be determined for key stakeholders. Furthermore, since a program includes a set of projects, another objective of this study is to find out whether the projects of program are accomplished, successfully or not. Therefore, to run this study, first literature of topic based on research keywords is reviewed. Then a conceptual model including all the aspects of program success factors is presented. Next, critical success factors are quantitatively analyzed by performing an empirical investigation on active organizations and firms of Iran's construction industry. The study employs questionnaire and performs interview surveys with construction program professionals and experts. Finally, the critical success factors of program are sorted according to their ranks. The results show that program-related factors maintain the highest effects on program success followed by organization-related and project-related issues.
\end{abstract}

\section{Introduction}

During the past years, extensive attempts have been taken to reach an agreement on many project management fields and the issue of "success" has attracted special attention. Concerning project success, several valuable studies have been conducted, which mostly focus on two dimensions of success, namely success criteria, the measures by which success or failure of a project or business will be judged, and success factors, those inputs to the management system that lead directly or indirectly to the success of the project or business (Cooke-Davies, 2002). However, success criteria and factors of program and large projects relating in benefits have not been fully investigated yet and

\footnotetext{
*Corresponding author.

E-mail addresses: sarmadkiani@ut.ac.ir (S. Kiani) 
there is not sufficient research about them (Arbabi et al., 2010). In terms of project management scientists' perspectives, program and project are basically different. Based on program definition and its position in organization, it is necessary to consider various levels of an organization such as project, program, and portfolio in terms of various points. Table 1 depicts the difference between these levels in terms of success (PMI, 2008).

\section{Table 1}

Difference between Project, Program and Portfolio in terms of Success

\begin{tabular}{llll}
\hline \multicolumn{1}{c}{ Projects } & \multicolumn{1}{c}{ Programs } & \multicolumn{1}{c}{ Portfolios } \\
\hline Success & $\begin{array}{l}\text { Success is measured by product } \\
\text { and project quality, timelines, } \\
\text { budget compliance, and degree of } \\
\text { customer satisfaction. }\end{array}$ & $\begin{array}{l}\text { Success is measured by the degree to } \\
\text { which the program satisfies the needs } \\
\text { and benefits for which it was } \\
\text { undertaken. }\end{array}$ & $\begin{array}{l}\text { Success is measured in terms of } \\
\text { aggregate performance of portfolio } \\
\text { components. }\end{array}$ \\
\hline
\end{tabular}

Moreover, most works on critical success factors (CSF) for construction projects are context-specific and the implications are limited to the countries where such studies have been conducted. It implies that more studies should be conducted in other countries to learn more about the nature and the structure of the local construction industry, scale of construction projects, procurement strategies, maturity of the concerned organizations, and local cultural values and norms (Toor et al., 2008). To the best of authors' knowledge, there is virtually no study on these issues in Iran. Therefore, the primary objective of this paper is to depict the program CSF aspects as a conceptual model and then by conducting empirical research and investigating the CSF of each aspect in mentioned context (construction), the study determines program critical success factors in Iran construction industry.

\subsection{Construction industry}

Construction industry as one of the most important project-oriented industries and having some unique features encompasses a variety of programs and their implementation plays essential role in countries' development. Construction is of the most prominent industries in all countries especially developing ones such as Iran in executing their national long-term and strategic programs. In recent years, the construction industry of Iran has been thriving due to an increase in national and international investment to the extent that it became of the largest in the Middle East region. Construction is also an appropriate context and choice in order to investigate the subject of Program Success because it may involve a variety of cases with different scales and functions. However, constructions projects and programs in Iran generally suffer from problems of performance failures, cost wastage, schedule delays, etc., which emphasizes on this study. Ashley et al. (1987) and Chan et al. (2004) present some of the characteristics of construction industry as follows,

- Involvement of many parties in delivering one product,

- Innovation and technology transfer is slow,

- Traditionally, design, construction, and maintenance are undertaken by different parties,

- The products are long lasting and require routine maintenance,

- Difficult to deliver a product, involves huge amount of information processing, disputes, ambiguities, therefore requires thorough management,

- Construction products are always initiated by clients, opposite to most of the industries,

It is also strongly influenced by political, environmental and social changes in Iran.

\subsection{Program}

Programs have been defined in some different ways; a long-term undertaking that includes two or more projects, which require close cooperation (Archibald, 2003) or a framework for grouping existing projects or defining new projects, and for focusing all the activities required to achieve a set of major benefits (Ferns, 1991; Pellegrinelli,1997). 
Programs also have been considered as large complex projects (Graham, 2000) or a set of projects and actions purposefully grouped to complete a transformation process and, thereby, realize strategic benefits (Miia \& Paivi, 2007). Program cannot be considered just as a scale-up of single projects (Lycett et al., 2004). A program is a temporary, flexible organization created to coordinate, direct and oversee the implementation of a set of related projects and activities in order to deliver outcomes and benefits related to the organization's strategic objectives (MSP, 2011). To have consensus on Program concept, in this paper the definition presented by Project Management Institute (PMI) has been taken into consideration. Program is a group of related projects managed in a coordinated way to obtain benefits and control not available from managing them individually (PMI, 2008). It is also very important to differentiate program from two other organizational levels, Project and portfolio, and their interactions.

Project is defined as a temporary endeavor undertaken to create a unique product, service or result. Projects focus on achieving their individual requirements. A program is comprised of multiple related projects initiated during the program's life cycle. The program manager coordinates efforts between projects but does not directly manage the individual projects. Programs concentrate on achieving the benefits aligned with the portfolio and, subsequently, organizational objectives.

A portfolio is a collection of components (i.e., projects, programs, portfolios, and other work such as maintenance and related ongoing operations), which are grouped together to facilitate the effective management of that work in order to meet strategic business objectives. The projects or programs of the portfolio may not necessarily be interdependent or directly related. Portfolio management focuses on assuring that programs and projects are selected, prioritized, and staffed with respect to their alignment with organizational strategies.

Programs are comprised of various components. Most of these components are the separate projects within the program, but another component is the management effort and infrastructure needed to manage the program. Thus, programs may include elements of related work (e.g. managing the program itself) outside the scope of the discrete projects in a program. It is helpful to have a deeper insight about above definition to create a success model for program. Actually, in forming model, we scrutinized the standard of program management and other related sources to acquire success route in the aspect of program based on the mentioned perception, "Program itself". The result was 25 Critical Success factors listed in Table 5.

\subsection{Critical Success Factors}

There is no doubt that all the parties and stakeholders of a program or project are interested in the success of a program. In other words, success is a climax for them. The concept of success factors is usually credited to Daniel (Daniel, 1961) who introduced it in association with the management information crisis (Fortune \& White, 2006). Rubin and Seeling (1967) first introduced the concept of project success factors in 1967 and Rockart (1982) used the terminology critical success factors (CSFs) for the first time (Toor, 2008):

“. . . the limited number of areas in which results, if they are satisfactory, will ensure successful competitive performance for the organization . . . . . . the few key areas where _things must go right_ for the business to flourish. . . . areas of activity that should receive constant and careful attention from management.. . . the areas in which good performance is necessary to ensure attainment of [organizational] goals”.

Researches and studies have indicated that most findings and conclusions summarized in a project level and the Project Success has been studied in many industries like Construction as well. Since projects are the components of Program, it is useful to review the studies carried out in project level. 
Table 2 summarizes the initial studies on project success factor under the title of organizational areas used in Westerveld model (Westerveld, 2003). Critical concern must be paid into attention, the difference between CSF and Success Criteria (SC). Belassi and Tukel (1996) asserted that a good research in this area should observe two features.1) Distinction between CSF and SC.2) Distinction between CSF under the control of project manager and CSF outside the control of project manager. De Wit (1988) and other writers distinguished between project success (measured against the overall objectives of the project) and project management success (measured against the widespread and traditional measures of performance against cost, time and quality) (Ahadzie et al., 2008; Baccarini, 1993; Cooke-Davies, 2002).

\section{Table 2}

Summary of initial research on critical success factors for projects

\begin{tabular}{|c|c|c|c|c|}
\hline $\begin{array}{l}\text { Areas(CSF for } \\
\text { projects) }\end{array}$ & Morris \& Hough & Munns \& Bjeirmi & Belassi \& tunkel & Pinto \& Slevin \\
\hline $\begin{array}{l}\text { Leadership and } \\
\text { team }\end{array}$ & Human factors & Human parties & Use of managerial skills & $\begin{array}{ll}- & \text { Personal recruitment } \\
\text { - } & \text { Trouble shooting }\end{array}$ \\
\hline $\begin{array}{l}\text { Policy and } \\
\text { strategy }\end{array}$ & Project definition & & Control and monitoring & \\
\hline $\begin{array}{l}\text { Stakeholder } \\
\text { management }\end{array}$ & Politics and social factors & $\begin{array}{c}\text { Relations with client } \\
\text { Politics }\end{array}$ & & $\begin{array}{ll}\text { - } & \text { Client consultation } \\
\text { - } & \text { Communication } \\
\text { - } & \text { Power and Politics }\end{array}$ \\
\hline Resources & Finance & & $\begin{array}{ll}\text { - } & \text { Use of technology } \\
\text { - } & \text { Preliminary estimates }\end{array}$ & \\
\hline Contracting & Legal agreements & $\begin{array}{l}\text { Legal agreements } \\
\text { Contracting }\end{array}$ & & \\
\hline $\begin{array}{c}\text { Project } \\
\text { management }\end{array}$ & Scheduling design & $\begin{array}{ll}\text { - } & \text { Project } \\
& \text { administration } \\
\text { - } & \text { Efficiency }\end{array}$ & Scheduling & Technical tasks \\
\hline External factors & $\begin{array}{ll}\text { - } & \text { Schedule } \\
\text { urgency } \\
\text { - } & \text { Schedule } \\
\text { duration }\end{array}$ & Objectives & $\begin{array}{ll}\text { - } & \text { Factors related to } \\
\text { project manger } \\
\text { - } & \text { Project team members } \\
\text { - Factors related to the } \\
\text { project } \\
\text { - Factors related to the } \\
\text { organization } \\
\text { - } \\
\text { Availability of } \\
\text { resources } \\
\text { - }\end{array}$ & $\begin{array}{ll}\text { - } & \text { Top management } \\
\text { support } \\
\text { - } & \text { Characteristics of } \\
\text { - } & \text { project manager } \\
\text { - } & \text { Environment events } \\
& \text { Urgency }\end{array}$ \\
\hline
\end{tabular}

There are valuable researches in Construction area as well. Table 3 summarizes the initial studies on Construction project success factors. In general, in this paper it is possibly aimed to utilize all the dominant and related studies to extract Construction Project Success Factors. In the following, these factors form our third aspect of model (Project level) listed in Table 6 by employing the view of experts and Professionals.

\section{Table 3}

Summary of initial research on critical success factors for Construction projects

\begin{tabular}{|c|c|c|c|c|c|}
\hline Chan et al. & Chua et al. & Nguyen et al. & Fortune \& White & Yu et al. & Toor et al. \\
\hline $\begin{array}{l}\text { Project team } \\
\text { commitment }\end{array}$ & Project characteristics & Comfort & Goals and objectives & $\begin{array}{l}\text { Project-related } \\
\text { factors }\end{array}$ & Comprehension \\
\hline $\begin{array}{l}\text { Contractor's } \\
\text { competencies }\end{array}$ & Contractual & Competence & Performance & $\begin{array}{l}\text { Human-related } \\
\text { factors }\end{array}$ & Competence \\
\hline $\begin{array}{l}\text { Risk and liability } \\
\text { assessment }\end{array}$ & Project participants & Commitment & Decision-maker(s) & $\begin{array}{l}\text { Process-related } \\
\text { factors }\end{array}$ & Commitment \\
\hline $\begin{array}{c}\text { Client’s } \\
\text { competencies }\end{array}$ & Interactive processes & Communication & Transformations & Input-related factors & Communication \\
\hline End-users' needs & & & Communication & $\begin{array}{l}\text { Output-related } \\
\text { factors }\end{array}$ & \\
\hline \multirow{4}{*}{$\begin{array}{l}\text { Constraints imposed } \\
\text { by end users }\end{array}$} & & & Environment & & \\
\hline & & & Boundaries & & \\
\hline & & & Resources & & \\
\hline & & & Continuity & & \\
\hline
\end{tabular}




\section{Research Method}

First, an extensive library research including the review of existing books, journals, papers, standards, models etc. were accomplished. This was carried out in valid and reliable sources in the field of project management, program management, critical success factors and success criteria of a project, program, organization, construction context, etc.

After realizing program success aspects, a conceptual model of program critical success factors was designed. Then a complete preliminary list of CSF for each aspect based on research studies was formed. This preliminary list was further refined by interviews with academic experts and practicing professionals in the Iran construction industry in a way that only those CSF of each aspect affects program success were finalized. The result was a list comprising 66 critical success factors, which formulated into questionnaire and distributed to program managers, construction project managers, scholars and academics involved in various Iran construction programs.

In order to fill in the questionnaires more precisely and give complementary explanations, questionnaires were answered in the presence of researcher. The 5-point Likert scale was adopted to determine the importance of each CSF. Finally, 30 completed questionnaires were obtained which yielded a response rate of over $95 \%$.

Since this research is categorized in quantitative approach, the SPSS software was used to evaluate the questionnaires' results. Then the process of conducting scientific research including data collection, analysis and conclusion were followed to identify and rank the program critical success factors of Iran construction industry.

\section{Results}

\subsection{Program success model}

Based on the implications of program, a conceptual model for program critical success factors can be assumed which has been constituted of 3 aspects. Fig. 1 indicates the components of model.

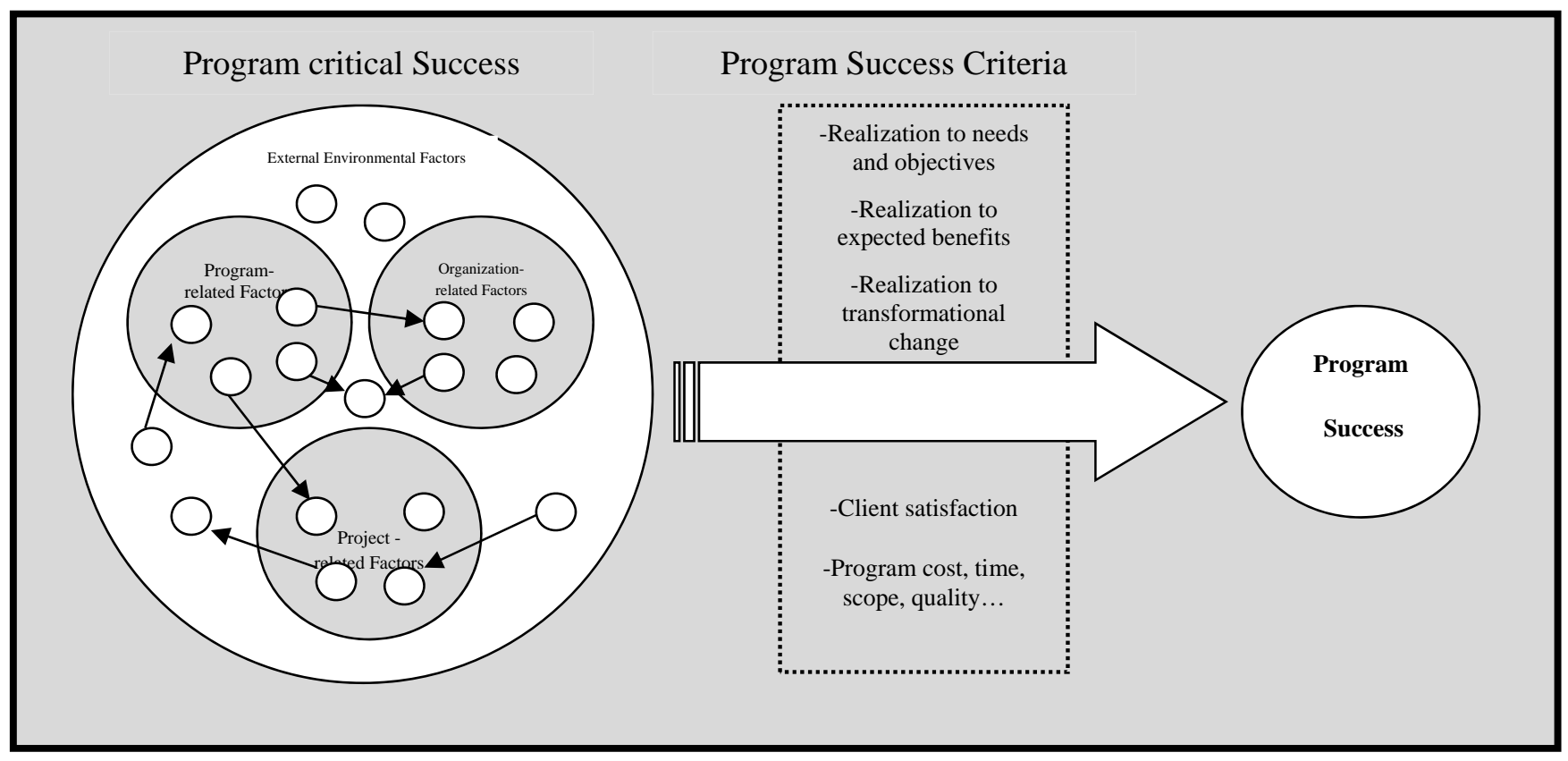

Fig. 1. Conceptual Model for Program Success 
First aspect concerns those CSF existing in organizational levels, which may influence programs success. These factors are mostly strategic and highly leveled and refer to organizational factors such as well-defined organization structure and culture, clear goals and objectives, top management supporting, etc., which provide bases to have successful programs. In this paper, they are called "Organization-related factors". Among many factors relating organization success in construction areas, by conducting face to face interview with experts and professionals, at last 17 factors were finalized and distributed to respondents in a form of questionnaire. These factors are listed in Table 4.

\section{Table 4}

Organization-related factors

\begin{tabular}{|cl}
\hline CSF & Description of CSF \\
\hline 1 & Right resource allocation to programs' projects \\
\hline 3 & Support from senior management \\
\hline 4 & Positive organizational Culture/structure \\
\hline 5 & Clearly written lines of responsibility \\
\hline 7 & Clear Strategy(vision, mission) \\
\hline 8 & Clear and realistic goals \\
\hline 10 & Recure employment in staffs and members \\
\hline 1 & Sufficient resource allocation \\
\hline 12 & Conducting regular evaluations of program and projects \\
\hline 13 & Complete feasibility studies \\
15 & Right Project financing \\
16 & Right Projects delivery system \\
\hline 17 & Right Projects parties and adequate communication among them \\
\hline
\end{tabular}

The second aspect is called "Program- related" factors. These factors have been defined in program level per se and include general factors such as program management, program key stakeholders, Program benefits, requirements, needs, etc. As mentioned in section 1-2, these factors have been extracted from namely references of program management mainly from standard of program management published by PMI. They are listed in Table 5 including 25 critical success factors.

Table 5

Program-related factors

\begin{tabular}{|c|c|}
\hline CSF & Description of CSF \\
\hline 18 & Clear and realistic goals, deliverables, benefits of program \\
\hline 19 & Effective change management \\
\hline 20 & Right risk management \\
\hline 21 & Effective Stakeholders management \\
\hline 22 & Using from Projects results in program \\
\hline 23 & Right cost estimates of program \\
\hline 24 & Right schedule estimates of program \\
\hline 25 & Proper allocation of Program budget to projects \\
\hline 26 & Proper allocation of Program time to projects \\
\hline 27 & Effective program cost management \\
\hline 28 & Effective program time management \\
\hline 29 & Effective program quality management \\
\hline 30 & Strategic alignment of Program goals with organization strategy \\
\hline 31 & Control disputes and conflicts by having good communication \\
\hline 32 & Coordinated performance of operational units \\
\hline 33 & Knowledge on the exact information needs of top management \\
\hline 34 & Using proven tools, techniques and processes in program management \\
\hline 35 & Competent program manager \\
\hline 36 & Having high relations between key benefits of program \\
\hline 37 & Focused and coordinated management to achieve strategic objectives \\
\hline 38 & considering mutual dependencies of components by program manager \\
\hline 39 & Strong and integrated Program management office \\
\hline 40 & Continuous financial support based on authorized budget \\
\hline 41 & Strong business case/charter for program \\
\hline 42 & Aligning and directing program components benefits toward strategic benefits \\
\hline
\end{tabular}

The third part refers to operational levels of an organization and can have a major role in final succession of programs. They are called "Project- related" factors. These factors have been defined in 
each project scope and the activities occur among projects. As noted in section 1-3 after using experts' views, they were finalized in Table 6 with 24 critical success factors.

\section{Table 6}

Project-related factors

\begin{tabular}{|c|c|}
\hline CSF & Description of CSF \\
\hline 43 & Clear and realistic goals of each project aligning strategic objectives \\
\hline 44 & Strong/detailed plan kept up to date \\
\hline 45 & Client involvement in each project \\
\hline 46 & Skilled/suitably qualified/sufficient staff/team \\
\hline 47 & Competent and experienced project managers \\
\hline 48 & Strong business case/charter /sound basis for projects \\
\hline 49 & Effective resource management in each project \\
\hline 50 & Using proper and related technology for construction work in each project \\
\hline 52 & Proper execution of each project based on predetermined cost plan \\
\hline 53 & Proper execution of each project based on predetermined quality plan \\
\hline 54 & Proper budget estimate for each project \\
\hline 55 & Proper time estimate for each project \\
\hline 56 & Right performance of all parties involved in project \\
\hline 57 & Appropriate education and training of project team \\
\hline 58 & Clear and detailed written contract for each project \\
\hline 59 & Awarding bids to the right designers/contractors... \\
\hline 61 & Client acceptance of plans \\
\hline 62 & Clear prioritization of each project goals \\
\hline 63 & Proven methodology of project management \\
\hline 64 & Proper dispute resolution clauses incorporated in the contract \\
\hline 65 & Adequate WBS linked with OBS(organization breakdown structure) \\
\hline 66 & Developing positive friendly relationships with team and stakeholders \\
\hline
\end{tabular}

It is necessary to be noted that another forth aspect can be regarded in this model under the title of "External environment" factors. These factors are outside the control of managers and may be reflected as proper risk management, stakeholder management, and complete feasibility studies in this model. The sources of most 66 factors are derived from the main studies listed in the references.

\subsection{Data analysis and Discussion}

After collecting all the questionnaires from respondents, their data were entered in SPSS software to be statistically analyzed. Table 7 shows the result and related statistical concepts. The factors have been sorted by their scores and listed from the highest importance to the lowest. The reliability of research is also provided in which regarding 66 factors addressed, Cronbach's Alpha was reached 0.958. The important point here is that all the investigated factors are critical for program success, but due to studied context and the perception of respondents, the listed factors were concluded for program critical success in Iran construction industry. The result represents that Support from top and senior management of program and project managers, proper cost estimates of program, Clear and realistic goals of each project, Clear and realistic goals, deliverables, benefits of program, Effective program cost management and proper schedule estimates of program have been realized as critical success factors from the viewpoint of Iran construction practitioners and experts. Another significant point deducted from results is that the most critical success factors relate to program aspect. Organization-related and then project-related factors have less factors among top list. It is obvious that from 10 highest critical success factors determined, 7 factors are program-related, 2 factors are organization-related and only one factor is project-related. Also concerning 10 factors acquired minimum scores, 3 factors are organization-related and 7 factors concern related projects aspect. After sorting the factors based on their mean score (highest) and then standard deviation score (lowest), in order to validate the results, we statistically analyzed the results by using a one-way ANOVA test. It can be assured that the findings of the sample can be generalized to the whole population. Therefore, using 5\% significance level, the construction program CSF's are ranked based on the experts' opinion. In this regard, seven CSF's are of the most importance and there is not a meaningful difference between them according to ANOVA analysis. They can be considered as top CSF's. These CSF's are as follows: 
1- Support from senior management

2- Clear and realistic goals, deliverables, benefits of program

3- Clear and realistic goals of each project aligning strategic objectives

4- Right cost estimates of program

5- Effective program cost management

6- Aligning and directing program components benefits toward strategic benefits

7- Right schedule estimates of program

Table 7

Critical Success Factors Ranking

\begin{tabular}{|c|c|c|c|c|c|c|}
\hline CSF & Rank & Description of CSF & Sum & M & SD & Aspect \\
\hline CSF2 & 1 & Support from senior management & 138 & 5 & 0.724 & Organization \\
\hline CSF23 & 2 & Right cost estimates of program & 138 & 5 & 0.885 & Program \\
\hline CSF18 & 3 & Clear and realistic goals, deliverables, benefits of program & 137 & 5 & 0.774 & Program \\
\hline CSF43 & 4 & Clear and realistic goals of each project aligning strategic objectives & 137 & 5 & 0.774 & Projects \\
\hline CSF27 & 5 & Effective program cost management & 136 & 5 & 0.819 & Program \\
\hline CSF24 & 6 & Right schedule estimates of program & 135 & 5 & 0.731 & Program \\
\hline CSF15 & 7 & Right Projects delivery system & 135 & 5 & 0.931 & Organization \\
\hline CSF42 & 8 & Aligning and directing program components benefits toward strategic benefits & 133 & 5 & 0.774 & Program \\
\hline CSF30 & 9 & Strategic alignment of Program goals with organization strategy & 133 & 5 & 1.006 & Program \\
\hline CSF40 & 10 & Continuous financial support based on authorized budget & 133 & 5 & 1.104 & Program \\
\hline CSF28 & 11 & Effective program time management & 131 & 4.5 & 0.809 & Program \\
\hline CSF14 & 12 & Right Project financing & 130 & 5 & 0.802 & Organization \\
\hline CSF38 & 13 & considering mutual dependencies of components by program manager & 129 & 4 & 0.702 & Program \\
\hline CSF1 & 14 & Right resource allocation to programs’ projects & 129 & 4 & 0.75 & Organization \\
\hline CSF37 & 15 & Focused and coordinated management to achieve strategic objectives & 129 & 5 & 1.055 & Program \\
\hline CSF13 & 16 & Complete feasibility studies & 126 & 4 & 0.925 & Organization \\
\hline CSF35 & 17 & Competent program manager & 125 & 4 & 0.747 & Program \\
\hline CSF44 & 18 & Strong/detailed plan kept up to date for each project & 125 & 4 & 0.834 & Projects \\
\hline CSF49 & 19 & Effective resource management in each project & 124 & 4 & 0.681 & Projects \\
\hline CSF19 & 20 & Effective change management & 123 & 4 & 0.803 & Program \\
\hline CSF25 & 21 & Proper allocation of Program budget to projects & 123 & 4 & 0.845 & Program \\
\hline CSF54 & 22 & Proper budget estimate for each project & 123 & 4 & 0.809 & Projects \\
\hline CSF33 & 23 & Knowledge on the exact information needs of top management & 121 & 4 & 0.928 & Program \\
\hline CSF16 & 24 & Right Projects parties and adequate communication among them & 121 & 4 & 0.695 & Organization \\
\hline CSF10 & 25 & Sufficient resource allocation & 120 & 4 & 0.743 & Organization \\
\hline CSF36 & 26 & Having high relations between key benefits of program & 120 & 4 & 1.083 & Program \\
\hline CSF21 & 27 & Effective Stakeholders management & 120 & 4 & 0.669 & Program \\
\hline CSF29 & 28 & Effective program quality management & 119 & 4 & 0.89 & Program \\
\hline CSF41 & 29 & Strong business case/charter for program & 119 & 4 & 0.785 & Program \\
\hline CSF48 & 30 & Strong business case/charter /sound basis for projects & 118 & 4 & 0.828 & Projects \\
\hline CSF20 & 31 & Right risk management & 118 & 4 & 0.571 & Program \\
\hline CSF32 & 32 & Coordinated performance of operational units & 116 & 4 & 0.9 & Program \\
\hline CSF526 & 33 & Proper allocation of Program time to projects & 116 & 4 & 0.937 & Program \\
\hline CSF39 & 34 & Strong and integrated Program management office & 116 & 4 & 0.95 & Program \\
\hline CSF52 & 35 & Proper execution of each project based on predetermined cost plan & 115 & 4 & 1.117 & Projects \\
\hline CSF11 & 36 & Conducting regular evaluations of program and projects & 115 & 4 & 1.064 & Organization \\
\hline CSF55 & 37 & Proper time estimate for each project & 114 & 4 & 0.858 & Projects \\
\hline CSF47 & 38 & Competent and experienced project managers & 113 & 4 & 1.104 & Projects \\
\hline CSF56 & 39 & Right performance of all parties involved in project & 113 & 4 & 0.952 & Projects \\
\hline CSF51 & 40 & Proper execution of each project based on predetermined schedule plan & 111 & 4 & 1.022 & Projects \\
\hline CSF6 & 41 & Clear Strategy(vision, mission) & 111 & 4 & 1.119 & Organization \\
\hline CSF62 & 42 & Clear prioritization of each project goals & 111 & 4 & 0.802 & Projects \\
\hline CSF31 & 43 & Control disputes and conflicts by having good communication & 110 & 4 & 1.028 & Program \\
\hline CSF34 & 44 & Using proven tools, techniques and processes in program management & 110 & 4 & 0.765 & Program \\
\hline CSF7 & 45 & Clear and realistic goals & 109 & 4 & 1.066 & Organization \\
\hline CSF22 & 46 & Using from Projects results in program & 109 & 4 & 0.817 & Program \\
\hline CSF59 & 47 & Awarding bids to the right designers/contractors... & 107 & 3 & 0.971 & Projects \\
\hline CSF5 & 48 & Clearly written lines of responsibility & 107 & 4 & 0.73 & Organization \\
\hline CSF3 & 49 & Positive organizational Culture/structure & 106 & 4 & 1.042 & Organization \\
\hline CSF46 & 50 & Skilled/suitably qualified/sufficient staff/team & 106 & 3 & 1.008 & Projects \\
\hline CSF58 & 51 & Clear and detailed written contract for each project & 104 & 3 & 1.224 & Projects \\
\hline CSF4 & 52 & Good communication and managing relationships & 104 & 3.5 & 0.898 & Organization \\
\hline CSF9 & 53 & Right delegation of authority and responsibility & 103 & 4 & 0.971 & Organization \\
\hline CSF60 & 54 & Learning from previous successful experiences & 103 & 3 & 0.615 & Projects \\
\hline CSF53 & 55 & Proper execution of each project based on predetermined quality plan & 101 & 3 & 1.155 & Projects \\
\hline CSF64 & 56 & Proper dispute resolution clauses incorporated in the contract & 100 & 3 & 0.915 & Projects \\
\hline CSF66 & 57 & Developing positive friendly relationships with team and stakeholders & 99 & 3 & 1.081 & Projects \\
\hline CSF12 & 58 & A realistic view on the possibilities and limitations of industry & 98 & 3 & 0.997 & Organization \\
\hline CSF63 & 59 & Proven methodology of project management & 96 & 3 & 1.126 & Projects \\
\hline CSF45 & 60 & Client involvement in each project & 96 & 3 & 0.96 & Projects \\
\hline CSF65 & 61 & Adequate WBS linked with OBS(organization breakdown structure) & 93 & 3 & 0.999 & Projects \\
\hline CSF8 & 62 & Secure employment in staffs and members & 89 & 3 & 1.098 & Organization \\
\hline CSF50 & 63 & Using proper and related technology for construction work in each project & 87 & 3 & 1.094 & Projects \\
\hline CSF57 & 64 & Appropriate education and training of project team & 87 & 3 & 1.185 & Projects \\
\hline CSF17 & 65 & Strategic alignment of project goals with adopted technology & 85 & 3 & 0.986 & Organization \\
\hline CSF61 & 66 & Client acceptance of plans & 78 & 2 & 1.003 & Projects \\
\hline
\end{tabular}


On the other hand, based on the ANOVA results, seven other CSF's are of the least importance. These CSF's have the same statistical significance and are as follows:

1- Client acceptance of plans

2- Appropriate education and training of project team

3- Secure employment in staffs and members

4- Using proper and related technology for construction work in each project

5- Strategic alignment of project goals with adopted technology

6- Proven methodology of project management

7- Adequate WBS linked with OBS(organization breakdown structure)

Table 7 shows the critical success factors ranking just based on the highest mean score and their corresponding aspects. (the scores are rounded).

\section{Conclusions}

Success in (Construction) Programs is an intact challenging issue and depends on various aspects. This study has asserted that program success may include organization-related factors, programrelated factors, project-related factors and factors associated with external environment.

This study reveals the top critical success factors of programs in Iranian construction industry. Although Support from senior management from organization-related factors ranked first by the view of expert respondents, analysis of this study shows that program-related factors have most CSF in Iran construction programs. Organization-related and projects-related are placed next. This issue can also provide a response to main question of study noted initially; critical success factors for projects are not necessarily the same as critical success factors for program but they may play a considerable role in program success. In other words, if all the projects of one program are successfully performed (measured by product and project quality, timelines, budget compliance, and degree of customer satisfaction), it will not be guaranteed to have successful program, because there are more aspects and factors which will affect it.

It is necessary to note that since this research was conducted in Iran's construction programs, findings should be interpreted in context of the Iran construction industry. Further researches can be felt in presenting program excellence model, which logically links success criteria and success factors and investigating inter-relationships between factors and may be suggested as future works.

\section{References}

Ahadzie, D. K., Proverbs, D. G., \& Olomolaiye, P. O. (2008). Critical success criteria for mass house building projects in developing countries. International Journal of Project Management, 26(6), 675-687.

Archibald, R.D. (2003). Managing high technology programs and projects. $3^{\text {rd }}$ ed. Hoboken, New Jersey USA: John Wiley and Sons.

Arbabi, H., Sobhieh, M.H., \& Nazari, A. (2010). Designing a conceptual model for program critical success factors. 5th International Project Management Conference.

Ashley, D.B., \& Laurie, C.S., \& Jaselskis, E.J. (1987).Determinants of construction project success, International Journal of Project Management, 18(2),69-79.

Baccarini, D. (1999). The logical framework method for defining project success. Project Management Institute, 30(4), 25-32.

Baker, B.N., Murphy, D.C., \& Fisher, D. (1988). Factors affecting project success. Project Management Handbook, ( $2^{\text {nd }}$ Ed.). New York: John Wiley.

Belassi, W., \& Tukel, Q. (1996). A new framework for determining critical success/failure factors in Projects. International Journal of Project Management, 14(3), 141-51.

Brown, A. \& Adams, J. (2000). Measuring the effect of project management on construction outputs: a new approach. International Journal of Project Management, 18, 327-35.

Cooke-Davies, T. (2002). The "real" success factors on projects. International journal of project 
management, 20(3), 185-190.

Chan, A.P.C., Ho, D.C.K., Tam, C.M. (2001). Design and build project success factors: multivariate analysis. Journal of Construction Engineering Management, ASCE, 127(2), 93-100.

Chan, A. P., Scott, D., \& Chan, A. P. (2004). Factors affecting the success of a construction project. Journal of Construction Engineering and Management,130(1), 153-155.

Chen, W.T. \& Chen, T.T. (2007). Critical success factors for construction partnering in Taiwan. International Journal of Project Management, 25, 475-484.

Cheng, E.W.L., Li, H., \& Love, P.E.D. (2000). Establishment of critical success factors for construction partnering. Journal of Management Engineering, 16(2), 84-92.

Chua, D.K., Kog, Y.C., Loh, P.K. (1999). Critical success factors for different project objectives. Journal of Construction Engineering Management, ASCE, 125(3), 142-150.

Cox, R.F., Issa, R.R.A. \& Ahrens, D. (2003). Management perception of key performance Indicators for construction. Journal of Construction Engineering Management, 129, 42-152.

Daniel, D.R. (1961). Management information crisis. Harvard Business Review, 111-121.

Ferns, DC. (1991). Development in programme management. International Journal of Project Management, 9(3), 148-156.

Fortune, J., \& White, D. (2006). Framing of project critical success factors by a systems model. International Journal of Project Management, 24, 53-65

Graham, A. K. (2000). Beyond PM 101: lessons for managing large development programs. Project Management Journal, 31(4), 7-18.

Kerzner, H. (1987). In search of excellence in project management. Journal of System Management, 38(2), 30 39.

Pellegrinelli, S. (1997). Programme management: organizing project-based change. International Journal of Project Management, 15(3), 141-149.

Miia, M., \& Paivi, L. (2007). Program and its initiation in practice: Development program initiation in a public consortium. International Journal of Project Management, 25, 337-345.

Morris, P. \& Hough, GH. (1987). The Anatomy of Major Projects. London: John Wiley and Sons.

Munns, A.K., \& Bjeirmi, A. (1996). The role of project management in achieving project success. International Journal of Project Management, 14, 81-87.

Mbachu, J., \& Nkado, R. (2007). Factors constraining successful building project implementation in South Africa. Journal of Construction Management Economics, 25, 39-54.

Managing Successful Programmes. (2011). OGC.

Nguyen, L.D., Ogunlana, S.O., \& Lan, D.T.(2994). A study on project success factors on large construction projects in Vietnam. Engineering Construction Architecture Management, 11(6), 404-413.

Lim, C.S., \& Mohammed, Z. (1999). Criteria of project success: an exploratory reexamination. International Journal of Project Management, 17,243-248.

Lycett, M., Rassau, A., \& Danson, J. (2004). Programme management: a critical review. International Journal of Project Management, 22(4), 289-299.

Pinto, J. K. (1986). Project implementation: a determination of its critical success factors, moderators and their relative importance across the project life cycle (Doctoral dissertation, University of Pittsburgh).

Pinto, J.K. \& Slevin, D.P. (1998). Critical success factors across the project. Project Management Journal, 19(3), 67-75.

Rubin, I. M., \& Seelig, W. (1967). Experience as a factor in the selection and performance of project managers. IEEE Transactions on Engineering Management, (3), 131-135.

Rockart, J. F. (1982). The changing role of the information systems executive: a critical success factors perspective. Massachusetts Institute of Technology, 23(3), 3-13.

The standard for program management-second edition. (2008).PMI.

Toor, S. U. R., \& Ogunlana, S. O. (2008). Critical COMs of success in large-scale construction projects: evidence from Thailand construction industry. International Journal of Project Management, 26(4), 420430.

Westerveld, E. (2003). The Project Excellence Model ${ }^{\circledR}$ : linking success criteria and critical success factors. International Journal of Project Management, 21(6), 411-418.

De Wit, A. (1988). Measurement of project success. International Journal of Project Management, 6(3), 164170.

Yu, A.T.W., Shen, Q., Kelly, J., \& Hunter, K. (2005). Investigation of critical success factors in construction project briefing by way of content analysis. Journal of Construction Engineering Management, 132(11), 1178-86. 